\title{
ANNONCES ET NOUVELLES
}

\section{GREETINGS}

This message is being sent to all philosophers and philosophy departments, institutions, societies, and research centers for whom we have electronic mail addresses. We encourage you to pass this information along, and we would especially be grateful if you would print and post this document.

This message concerns an upcoming event which should interest philosophers from around the globe:

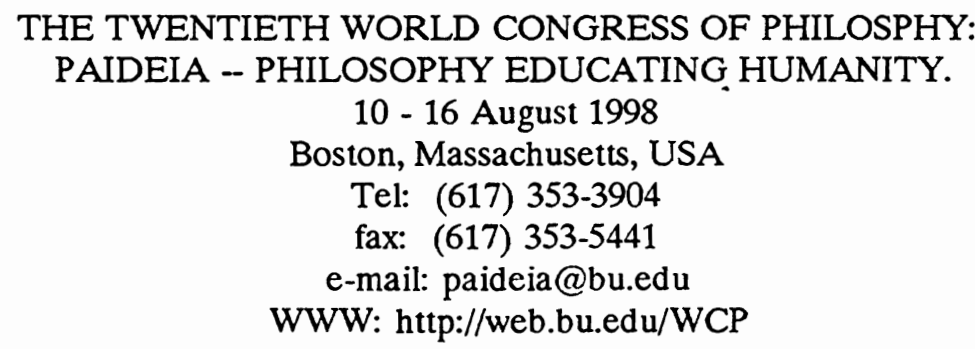

The World Congresses of the International Federation of Philosophical Societie (FISP) are normally held every five years. The Twentieth World Congress of Philosphy, to be held in Boston in 1998, will follow previous Congresses in developing a main theme while remaining as open as possible to the full diversity of philosophical issues, traditions and approaches.

Posters have been recently mailed worldwide. Updated information is always available at our website, and it will soon be available in several languages:

http://web.bu.edu/WCP

Below you will find information about: Registration, Call for Papers, group Space requests, and much more! We are especially eager to assist those societies and organizations that wish to hold their meetings/ /conferences withing the framework of the 20th WCP.

Plenary Sessions and Symposia:

The Twentieth Congress in Boston will develop the main of Paideia under several headings. 


\section{Invited Séssions:}

The Program of this Congress will include a large number of invited sessions. The best contemporary work in our field will be represented. Complete detail on this aspect of the Program will be provided in the final circular.

\section{Call for papers:}

More than forty five sections invite contributed papers.

\section{Other Sessions Inviting Proposals:}

Proposals are invited for Round Tables on other more specific topics in philosophy. Proposed slates of participants should include some international diversity, and participants must be registered for the Congress. Topics and organizers are subject to approval by the Program Committee.

\section{Contributed Papers Should be Submitted as Follows:}

Ten (10) pages, 3000 words; three (3) copies, typed, with $1.5 \mathrm{~cm}$ margins on all sides of text; accompanied by a twenty (20) line abstract. If possible, send papers on a high-density (HD) compiter disk in ASCII or "text only" format. Papers may also be submitted electronically to our email address.

The Program Committee reserves the right to accept or reject papers on the basis of criteria of quality. Only texts of a philosophical nature will be considered for inclusion in the program.

\section{Important dates:}

September 1, 1997, is the deadline for contributed papers, poster session theses, and poposals for round tables. Papers and other contributions received after this dealine but before 1 January 1998, may be accepted if space is still available.

Please send all proposals and papers to the American organizing Committee, Inc., at the address listed below. 
Meetings" of Philosophical Societies:

Philosophical societies are encouraged to meet in conjunction with the Congress. Meeting rooms will be provided at no extra cost. Representatives of societies or research centers are asked to submit written requests for space by the end of August 1997.

Send all correspondence to following address:

American Organizing Committee, Inc.

Boston University

745 Commonwealth Avenue

Boston, Massachusetts 02215 (USA)

Registration Fee:

$\$ 150.00$ before 1 June 1997

$\$ 175.00$ before 1 January 1998

$\$ 200.00$ after 1 January 1998

$\$ 75.00$ Student/Spouse

$\$ 75.00$ Single Day

If so, please specify day 